A C T A C H M I CA SCA N I N A VICA 21 (1967) $359-370$

\title{
The Crystal and Molecular Structure of Methyl Phenyl Phospholanium Iodide
}

\author{
EYVIND ALVER and BRIT HELEN HOLTEDAHL
}

Chemical Institute, University of Bergen, Bergen, Norway

\begin{abstract}
The crystals of methyl phenyl phospholanium iodide are orthorhombic, space group $P 2_{1} 2_{1} 2_{1}$, with cell dimensions $a=10.43$ $\AA, b=18.41 \AA, c=6.55 \AA$. There are four formula units $\mathrm{CH}_{3}\left(\mathrm{C}_{6} \mathrm{H}_{5}\right) \mathbf{P}\left(\mathrm{CH}_{2}\right)_{4} \mathbf{I}$ in the unit cell.

The crystal and molecular structure has been determined by $X$-ray methods, including three-dimensional least squares refinement. The final agreement residual $R_{1}$ is 0.07 for 1007 observed structure amplitudes. Standard deviations in bond lengths are from 0.02 to $0.03 \AA$, and standard deviations in bond angles from 1 to $2.4^{\circ}$. The phosphorus atom, the phenyl group, and the carbon atom of the methyl group are nearly coplanar. The angle at the phosphorus atom in the phospholane ring is $95^{\circ}$. This ring is not planar, presumably because of hydrogen-hydrogen repulsion, and is asymmetrical, possibly because the groups attached to the phosphorus atom are not equal, but also possibly because of inter-ionic forces. The mean phosphorus-carbon distance is found to be $1.77 \AA$; none of the four such bonds deviate significantly from the mean value.
\end{abstract}

Tt was reported by Aksnes and Bergesen ${ }^{1}$ that the five-membered cyclic 1 phosphonium ion, $\mathrm{CH}_{3}\left(\mathrm{C}_{6} \mathrm{H}_{5}\right) \mathrm{P}^{+}\left(\mathrm{CH}_{2}\right)_{4}$, undergoes alkaline hydrolysis very much faster than the six-membered analog, $\mathrm{CH}_{3}\left(\mathrm{C}_{6} \mathrm{H}_{5}\right) \mathrm{P}^{+}\left(\mathrm{CH}_{2}\right)_{5}$, under the same conditions. They concluded that the difference in reaction rate is due to a larger frequency factor in the case of the phospholane derivative, and believed that this might be explained by the molecular structure of the five-membered ring. At that time no structure determination of a saturated five-membered ring containing phosphorus had been published, nor had, as far as we knew, any structure anlysis of a phosphonium salt been carried out. The present work was started with the hope that it might contribute to the understanding of the reactions of phosphonium salts and of cyclic phosphorus compounds, and to the structural chemistry of saturated five-membered ring systems in general. 


\section{STRUCTURE ANALYSIS}

Methyl phenyl phospholanium iodide, $\mathrm{CH}_{3}\left(\mathrm{C}_{6} \mathrm{H}_{5}\right) \mathrm{P}\left(\mathrm{CH}_{2}\right)_{4} \mathrm{I}$, crystallized by evaporation of water solution, is orthorhombic, space group $P 2_{1} 2_{1} 2_{1}$ (No. 19). The cell dimensions, $a=10.43 \AA, b=18.41 \AA, c=6.55 \AA$, were determined

Table 1. Final positional parameters of one asymmetric unit in fractions of the corresponding cell edge.

\begin{tabular}{|c|c|c|c|}
\hline & $x$ & $y$ & $z$ \\
\hline I & 0.3774 & 0.1394 & 0.1042 \\
\hline $\mathbf{P}$ & 0.5836 & 0.3674 & 0.3508 \\
\hline $\mathrm{C}_{1}$ & 0.5097 & 0.3442 & 0.5821 \\
\hline $\mathrm{C}_{2}$ & 0.5170 & 0.2603 & 0.6056 \\
\hline $\mathrm{C}_{3}$ & 0.6267 & 0.2364 & 0.4876 \\
\hline $\mathrm{C}_{4}$ & 0.6345 & 0.2773 & 0.2945 \\
\hline $\mathrm{C}_{5}$ & 0.7166 & 0.4280 & 0.3921 \\
\hline $\mathrm{C}_{6}$ & 0.4726 & 0.4026 & 0.1740 \\
\hline $\mathrm{C}_{7}$ & 0.4967 & 0.4689 & 0.0699 \\
\hline $\mathrm{C}_{8}$ & 0.4050 & 0.4946 & -0.0619 \\
\hline $\mathrm{C}_{9}^{\circ}$ & 0.2910 & 0.4596 & -0.0929 \\
\hline $\mathrm{C}_{10}^{\circ}$ & 0.2719 & 0.3952 & 0.0019 \\
\hline $\mathrm{C}_{11}$ & 0.3562 & 0.3665 & 0.1290 \\
\hline $\mathrm{H}_{11}$ & 0.411 & 0.340 & 0.552 \\
\hline $\mathrm{H}_{12}$ & 0.520 & 0.398 & 0.627 \\
\hline $\mathbf{H}_{21}$ & 0.438 & 0.245 & 0.531 \\
\hline $\mathrm{H}_{22}$ & 0.487 & 0.238 & 0.700 \\
\hline $\mathrm{H}_{31}$ & 0.595 & 0.182 & 0.493 \\
\hline $\mathrm{H}_{32}$ & 0.696 & 0.245 & 0.600 \\
\hline $\mathbf{H}_{41}$ & 0.575 & 0.256 & 0.167 \\
\hline $\mathrm{H}_{42}$ & 0.699 & 0.282 & 0.167 \\
\hline $\mathbf{H}_{51}$ & 0.806 & 0.417 & 0.478 \\
\hline $\mathrm{H}_{52}$ & 0.682 & 0.475 & 0.444 \\
\hline $\mathbf{H}_{53}$ & 0.773 & 0.437 & 0.267 \\
\hline $\mathrm{H}_{71}$ & 0.580 & 0.496 & 0.131 \\
\hline $\mathbf{H}_{81}$ & 0.423 & 0.540 & -0.110 \\
\hline $\mathbf{H}_{91}$ & 0.207 & 0.479 & -0.200 \\
\hline $\mathrm{H}_{101}$ & 0.186 & 0.362 & -0.038 \\
\hline $\mathrm{H}_{111}$ & 0.345 & 0.315 & 0.173 \\
\hline
\end{tabular}

Table 2. Anisotropic vibration parameters for the iodide ion, the phosphorus atom, and the carbon atoms. The expression used is exp $-\left(\beta_{13} h^{2}+\beta_{22} k^{2}+\beta_{33} l^{2}+\beta_{12} h k+\beta_{23} k l+\beta_{13} h l\right) . .^{14}$ An isotropic temperature factor exp-2.5( $\sin \theta / \lambda)^{2}$ was used for the hydrogen atoms.

\begin{tabular}{|c|c|c|c|c|c|c|}
\hline & $\beta_{11}$ & $\beta_{22}$ & $\beta_{33}$ & $\beta_{23}$ & $\beta_{13}$ & $\beta_{12}$ \\
\hline I & 0.0132 & 0.0025 & 0.0252 & 0.0036 & -0.0033 & -0.0019 \\
\hline $\mathbf{P}$ & 0.0084 & 0.0019 & 0.0135 & -0.0020 & -0.0011 & 0.0003 \\
\hline $\mathbf{C}_{1}$ & 0.0180 & 0.0042 & 0.0140 & 0.0015 & -0.0049 & -0.0006 \\
\hline $\mathrm{C}_{2}$ & 0.0155 & 0.0044 & 0.0354 & 0.0110 & 0.0078 & -0.0038 \\
\hline $\mathrm{C}_{3}$ & 0.0081 & 0.0039 & 0.0449 & 0.0145 & -0.0010 & 0.0035 \\
\hline $\mathrm{C}_{4}$ & 0.0134 & 0.0021 & 0.0260 & 0.0040 & -0.0040 & -0.0032 \\
\hline $\mathrm{C}_{5}$ & 0.0104 & 0.0022 & 0.0443 & 0.0007 & -0.0039 & -0.0003 \\
\hline $\mathrm{C}_{6}^{\circ}$ & 0.0077 & 0.0022 & 0.0193 & 0.0045 & 0.0053 & 0.0021 \\
\hline $\mathrm{C}_{7}^{6}$ & 0.0154 & 0.0026 & 0.0172 & -0.0003 & -0.0062 & 0.0036 \\
\hline $\mathrm{C}_{8}$ & 0.0072 & 0.0036 & 0.0446 & 0.0117 & 0.0059 & 0.0031 \\
\hline $\mathrm{C}_{9}^{\circ}$ & 0.0095 & 0.0039 & 0.0303 & -0.0018 & -0.0116 & 0.0014 \\
\hline $\mathrm{C}_{10}$ & 0.0114 & 0.0044 & 0.0314 & 0.0003 & -0.0227 & -0.0017 \\
\hline $\mathrm{C}_{11}$ & 0.0088 & 0.0025 & 0.0291 & 0.0008 & 0.0024 & 0.0010 \\
\hline
\end{tabular}


Table 3. Observed and calculated structure amplitudes. No value for $F_{0}$ is given when it is supposed that the intensity is not measured with reasonable accuracy.

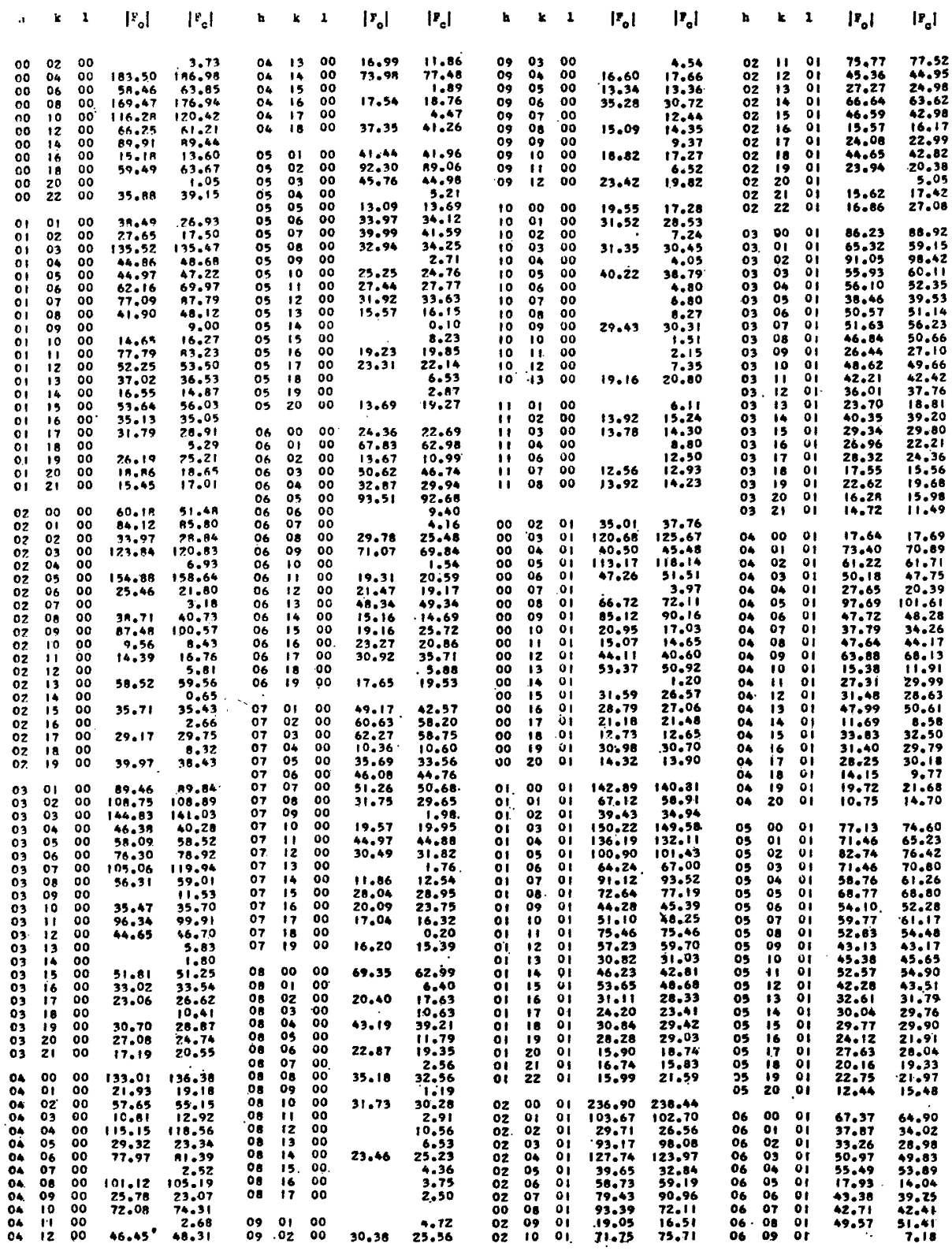




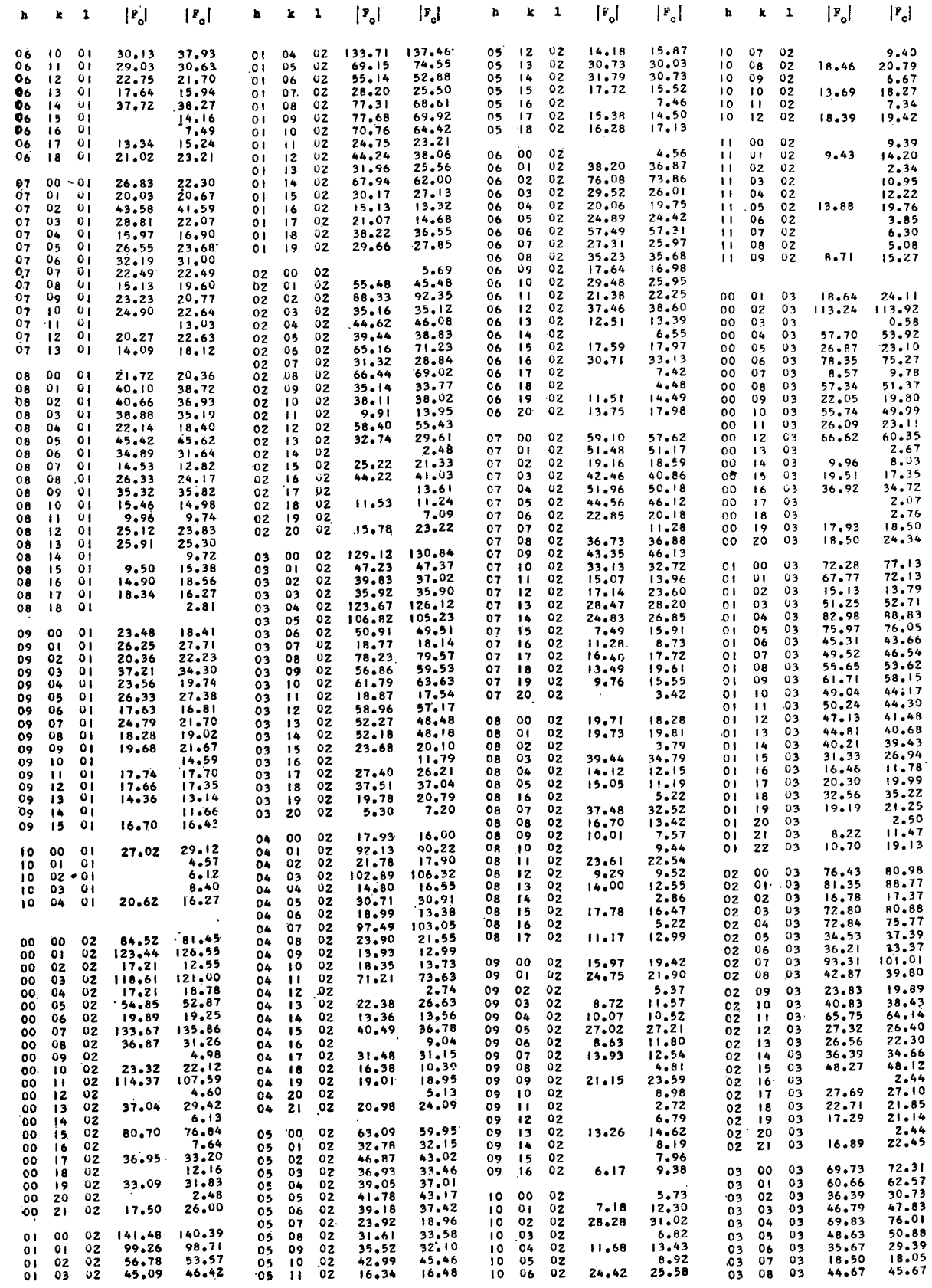

Acta Chem. Scand. 21 (1967) No. 2 
METHYL PHENYL PHOSPHOLANIUM IODIDE

\begin{tabular}{|c|c|c|c|}
\hline h & $k$ & 1 & $\left|F_{0}\right|$ \\
\hline 03 & 09 & $0_{3}$ & 50.56 \\
\hline 03 & 10 & U3 & 46.40 \\
\hline 03 & 11 & 03 & 15.98 \\
\hline 03 & 12 & 03 & 15.21 \\
\hline 03 & 13 & c3 & 39.94 \\
\hline 03 & 14 & 03 & 40.08 \\
\hline 03 & 15 & 03 & 14.66 \\
\hline 03 & 16 & 03 & 12.84 \\
\hline 03 & 17 & 03 & 19.03 \\
\hline 03 & 18 & 03 & 22.18 \\
\hline 03 & 19 & 03 & 9.47 \\
\hline 03 & 20 & 03 & \\
\hline 03 & 21 & 03 & 9.88 \\
\hline & & & \\
\hline 04 & 00 & 03 & 22.58 \\
\hline 04 & 01 & u3. & 28.56 \\
\hline 04 & 02 & 03 & 71.55 \\
\hline 04 & 03 & 03 & 15.91 \\
\hline 04 & 04 & 03 & 28.35 \\
\hline 04 & 05 & 03 & 24.44 \\
\hline 04 & 06 & 03 & 48.97 \\
\hline 04 & 07 & 03 & 17.31 \\
\hline 04 & $O B$ & 03 & 40.15 \\
\hline 04 & 09 & 03 & 31.10 \\
\hline 04 & 10 & 03 & 38.78 \\
\hline 04 & 11 & 03 & 18.62 \\
\hline 04 & 12 & 03 & 39.64 \\
\hline 04 & 13 & 03 & 10.00 \\
\hline 04 & 14 & 03 & 16.00 \\
\hline 04 & 15 & 03 & 20.32 \\
\hline 04 & 16 & 03 & 33.16 \\
\hline 04 & 17 & 03 & \\
\hline 04 & 18 & 03 & 7.02 \\
\hline 04 & 19 & 03 & 11.94 \\
\hline 04 & 20 & 03 & 15.41 \\
\hline 05 & 00 & 03 & 63.71 \\
\hline 05 & 01 & 03 & 49.56 \\
\hline 05 & 02 & 03 & 34.01 \\
\hline 05 & 03. & 03 & 41.38 \\
\hline 05 & 04 & 03 & 60.93 \\
\hline 05 & 05 & 03 & 44.97 \\
\hline C5 & 06 & 03 & 33.12 \\
\hline on & 07 & 03 & 33.00 \\
\hline 05 & 08 & 03 & 46.38 \\
\hline 05 & 09 & 03 & 34.67 \\
\hline 05 & 10 & 03 & 35.04 \\
\hline 05 & 11 & $v_{3}$ & 26.82 \\
\hline 05 & 12 & $0_{3}$ & 28.35 \\
\hline 05 & 13 & 03 & 28.78 \\
\hline 05 & 14 & 03 & 26.03 \\
\hline 05 & 15 & 03 & 23.55 \\
\hline 05 & 16 & 03 & 17.94 \\
\hline 05 & 17 & 03 & 15.24 \\
\hline 05 & 18 & 03 & 17.21 \\
\hline 05 & 19 & 03 & 10.38 \\
\hline & & & \\
\hline 06 & 00 & 03 & 23.43 \\
\hline 06 & 01 & 03 & 38.63 \\
\hline 06 & 02 & 03 & \\
\hline 06 & 03 & 03 & 56.49 \\
\hline 06 & 04 & 03 & 28.77 \\
\hline $\begin{array}{l}06 \\
06\end{array}$ & 05 & 03 & 23.86 \\
\hline $\begin{array}{l}0 \\
0\end{array}$ & 06 & 03 & 16.73 \\
\hline $\begin{array}{l}0 \\
0\end{array}$ & 07 & 03 & 53.46 \\
\hline $\begin{array}{l}06 \\
\text { of }\end{array}$ & 08 & 03 & 5.33 \\
\hline 06 & $\begin{array}{l}09 \\
10\end{array}$ & 03 & 3.42 \\
\hline & 10 & 03 & 16.85 \\
\hline 06 & 12 & $\begin{array}{l}03 \\
03\end{array}$ & $\begin{array}{l}33.00 \\
15.96\end{array}$ \\
\hline 06 & 13 & 03 & 18.82 \\
\hline Q6 & 14 & 03 & 18.54 \\
\hline 06. & 15 & 03 & 24.09 \\
\hline 06 & 16 & 03 & \\
\hline 06 & 17 & 03 & 14.76 \\
\hline OS. & 18 & 03 & 12.4 \\
\hline & & & \\
\hline 07 & 00 & & 25.4 \\
\hline & & 0 & \\
\hline 07 & v2 & $u$ & 8.6 \\
\hline c7 & 03 & 0 & \\
\hline 07 & 04 & 03 & 19.59 \\
\hline 07 & 05 & 03 & 29.93 \\
\hline 07 & 06 & 03 & 19.8 \\
\hline 07 & 07 & 03 & \\
\hline c7 & $O B$ & 03 & \\
\hline 07 . & 09 & 03 & 26.82 \\
\hline 07 & 10 & 03 & 16.54 \\
\hline 0 & i & 0 & \\
\hline 0 & 12 & 0 & 9.2 \\
\hline 07 & 13 & 03 & 22.03 \\
\hline 07 & 14 & 03 & 11.94 \\
\hline of & 15 & 03. & \\
\hline 07 & & i) 3 & 4.39 \\
\hline 07 & 17 & 03 & 12.91 \\
\hline & & & \\
\hline
\end{tabular}

Acta Chem. Scand. 21 (1967) No. 2 


\begin{tabular}{|c|c|c|c|c|c|c|c|c|c|c|c|c|c|c|c|c|c|c|c|}
\hline h & $k$ & 2 & $\left|P_{0}\right|$ & $\left|F_{c}\right|$ & h & $k$ & 1 & $\left|p_{0}\right|$ & $\left|x_{c}\right|$ & h & $k$ & 1 & $\left|F_{0}\right|$ & $\left|{ }_{\mathrm{c}}\right|$ & h & $k$ & 1 & $\left|p_{0}\right|$ & $\left|P_{s}\right|$ \\
\hline oz & 11 & 05 & 1.61 & 18.75 & 34 & 09 & OS & 41.96 & 41.66 & 06 & 09 & os & 4.95 & 7.70 & 10 & 02. & $0_{5}$ & & 5.35 \\
\hline 02 & 12 & 05 & & 0.77 & 04 & 10 & 05 & & 13.98 & os & 10 & 05 & 21.39 & 20.41 & 10 & 03 & 05 & & 4.21 \\
\hline 02. & 13 & os & & 8.06 & 04 & 11 & us & & 14.99 & 06 & 11 & 05 & & 1.87 & 10 & 04 & 05 & 0.14 & 11.00 \\
\hline 2 & 14 & 05 & 34.43 & 34.04 & 04 & 12 & 05 & & 4.26 & Oo & 12 & us & 14.70 & 12.78 & 10 & 05 & 05 & & 5.03 \\
\hline 02 & is & 05 & 7.80 & 7.55 & $\begin{array}{l}04 \\
04\end{array}$ & 12 & 05 & 26.47 & 27.17 & 06 & 13 & U5 & 3.91 & 5.12 & 10 & 06 & 05. & & 9.95 \\
\hline 02 & 16 & $\begin{array}{l}05 \\
05\end{array}$ & $\begin{array}{r}10.47 \\
9.50\end{array}$ & $\begin{array}{l}6.41 \\
9.72\end{array}$ & .04 & 14 & $\begin{array}{l}05 \\
05\end{array}$ & $\begin{array}{r}4.39 \\
13.62\end{array}$ & $\begin{array}{l}10.16 \\
17.72\end{array}$ & 06 & 14 & 05 & & 20.73 & & & & & \\
\hline & 18 & 05 & & 26.97 & $\begin{array}{l}04 \\
04\end{array}$ & $\begin{array}{l}15 \\
16\end{array}$ & 05. & & 2.66 & 07 & 00 & 05 & 9.09 & 7.93 & 00 & 00 & 06 & 27.81 & 25.50 \\
\hline & & & & & 04 & 17 & 05 & 12.56 & 16.12 & 07 & 01 & 05 & 17.70 & 12.20 & 00 & 01 & 06 & 33.50 & 29.11 \\
\hline 03 & 00 & 05 & 11.48 & 9.59 & & & & & & 07 & 02. & 05 & 22.15 & 25.36 & & 02 & 06 & & \\
\hline 03 & 01 & 09 & 22 . & 22.53 & 05 & 00 & 05 & 18.98 & 16.94 & 07 & 03 & 05 & 19.22 & 16.36 & 00 & 03 & 06 & 40.21 & 34.92 \\
\hline 03 & 02 & 05 & 2.60 & 42.46 & 05 & 01 & 05 & 21.54 & 24.14 & 07 & 0.4 & 05 & & 7.87 & 00 & 04 & 06 & & 12.73 \\
\hline 03 & 03 & 05 & 8.73 & 29.08 & os & 02 & 05 & 26.26 & 26.53 & 07 & 05 & 05 & & 4.71 & 00 & 05 & 06 & & 13.53 \\
\hline 03 & 04 & 05 & $0^{\circ}$ & 12.14 & 05 & 03 & 05 & 23.80 & 24.19 & 07 & 06 & 05 & 19.64 & 19.80 & 00 & 06 & Of & 17. & 17.80 \\
\hline 03 & 05 & 05 & 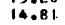 & 16.24 & 05 & 04 & 05 & .17 .93 & 15.90 & 07 & 07 & 05 & 19 & 18.98 & 00 & 07 & 06 & 36.75 & 36.24 \\
\hline 03 & 06 & 05 & 2 & & 05 & 05 & Us & 14.72 & 17.32 & 07 & ${ }_{0 B}$ & 05 & 13.39 & 14.65 & 00 & og & 06 & & 11.23 \\
\hline 03 & 07 & 05 & 7 & 33. & os & 06 & 05 & 24.29 & 20.03 & 07 & 00 & 05 & & & 00 & 09 & 06 & & 9.38 \\
\hline $\begin{array}{l}33 \\
03\end{array}$ & OB & 05 & 5 & 20.11 & 05 & 07 & 05 & 29.25 & 31.53 & $\begin{array}{l}07 \\
07\end{array}$ & 10 & 05 & 13.31 & 130 & 00 & 10 & 06 & 19.57 & 21.41 \\
\hline 03 & 09 & 05 & & 12.64 & 05 & $O_{8}$ & 05 & 20. & 22.65 & 07 & 11 & 45 & 10.28 & 13.0 & 00 & $i 1$ & 06 & 24. & 26.53 \\
\hline 03 & 10 & 05 & 20. & 21.38 & 05 & 09 & 05 & 12.6 & 13.15 & 07 & 12 & os & 12.71 & 15.5 & Do & 12 & 06 & 9.54 & 7.21 \\
\hline 03 & ii & 05 & 25.2 & 24. & 05 & 10 & 05 & 15. & 15.25 & 07 & 13 & 05 & 9.07 & 5.98 & 00 & 13 & 06 & 13.00 & 10.80 \\
\hline 03 & 12 & US & 24. & 24.56 & 05 & $1 i$ & 05 & 24.76 & 27.89 & 07 & 14 & 05 & 5.03 & 8.33 & 00 & 16 & 06 & & \\
\hline 03 & 13 & 05 & 16. & 14.04 & 05 & 12 & .05 & 18. & 21.70 & & & & & & 00 & 15 & 06 & 13.16 & 15.12 \\
\hline 03 & 14 & 05 & 10. & 12.15 & 05 & 13 & 05 & 10. & 9.48 & 09 & 00 & 05 & & 1.28 & & & & & \\
\hline 03 & 15 & 05 & & & 05 & 14 & 05 & 10.26 & 9.02 & 09 & 01 & 05 & 12.56 & & 00 & 00 & 07 & & 0.00 \\
\hline 03 & 16 & 05 & & 18.94 & 05 & 15 & 05 & 14. & 16.4 & 09 & 02 & os & & & 00 & 01 & of & & 7.26 \\
\hline 03 & 17 & 05 & & 15.31 & 05 & 16 & 05 & 10. & 14. & 09 & 03 & 05 & 14.55 & 17.21 & 00 & 02 & 07 & 36.53 & 37.63 \\
\hline & & 05 & & 1.98 & 05 & 17 & & & & $\begin{array}{l}09 \\
09\end{array}$ & $\begin{array}{l}04 \\
05\end{array}$ & $\begin{array}{l}05 \\
05\end{array}$ & $\begin{array}{r}4.08 \\
11.23\end{array}$ & $\begin{array}{r}2.87 \\
3.08\end{array}$ & 00 & 03 & $\begin{array}{l}07 \\
07\end{array}$ & 12,097 & $\begin{array}{l}11.64 \\
10.72\end{array}$ \\
\hline 04 & 01 & 05 & 51.45 & 55.75 & 06 & 00 & OS & 30.34 & 32.71 & $\begin{array}{l}09 \\
09\end{array}$ & $\begin{array}{l}05 \\
06\end{array}$ & $\begin{array}{l}05 \\
05\end{array}$ & & $\begin{array}{r}13.08 \\
6.42\end{array}$ & 00 & 05 & 07 & & 6.20 \\
\hline 04 & 02 & 05 & 9.34 & 5.77 & 06 & 01 & 0 & & & 09 & 07 & 05 & 12.44 & 12. & & 06 & 07 & 23.60 & 26.74 \\
\hline 04 & 03 & 05 & 27.40 & 27. & 06 & 03 & ') & & & 09 & 08 & 05 & & 3. & & 07 & 07 & & \\
\hline 04 & 04 & 05 & & 5.28 & 06 & 04 & us & 39.45 & 42.1 & 00 & 09 & 05 & R.82 & 10.00 & & $O_{B}$ & 07 & 16.12 & \\
\hline 04 & 05 & 05 & 44.72 & 46. & 06 & 05 & 05 & 5.22 & 3.74 & & & & & & 0 & 09 & 07 & & 14.15 \\
\hline 04 & 06 & 05 & & 2.99 & 06 & 06 & 05 & 22.09 & 21.52 & 10 & 00 & 05 & 9.31 & 11.82 & 00 & 10 & 07 & 17.26 & 17.84 \\
\hline 04 & $\begin{array}{l}07 \\
08\end{array}$ & $\begin{array}{l}05 \\
05\end{array}$ & 27.05 & $\begin{array}{r}20.55 \\
8.24\end{array}$ & $\begin{array}{l}06 \\
06\end{array}$ & $\begin{array}{l}07 \\
08\end{array}$ & $\begin{array}{l}0.5 \\
03\end{array}$ & $\begin{array}{r}5.14 \\
23.53\end{array}$ & $\begin{array}{r}3.79 \\
76.26\end{array}$ & 10 & 01 & 05 & & 4.15 & 00 & 11 & 07 & & 8.97 \\
\hline
\end{tabular}

from Weissenberg diagrams of very small crystals, powdered with finely ground sodium chloride, and rotated around the $a$ and $c$ axes.

The intensities of the reflections were measured with a photometer on integrated Weissenberg equi-inclination diagrams. The usual multifilm technique was employed, and in all 1007 independent intensities of the orders $h k 0-h k 5$ and $0 k l$ were measured. The intensities were corrected in the normal way, a spot shape correction being used for the higher layers, where only the extended spots were measured. ${ }^{2}$ As all crystals used were very small, no absorption correction was thought necessary, but at a later stage of the structure analysis the reflections of low order were corrected for secondary extinction. ${ }^{3}$

The positions of the iodide ions were determined from Patterson projections along $a$ and $c$. Phases were computed from the coordinates of the iodide

Table 4. Bond distances in the methyl phenyl phospholanium ion and their standard deviations.

$\begin{array}{lcc}\text { Bond } & (l) \AA & \sigma(l)(\AA) \\ \mathrm{P}-\mathrm{C}_{1} & 1.75 & 0.02 \\ \mathrm{P}-\mathrm{C}_{4} & 1.78 & 0.02 \\ \mathrm{P}-\mathrm{C}_{5} & 1.80 & 0.02 \\ \mathrm{P}-\mathrm{C}_{8} & 1.76 & 0.02 \\ \mathrm{C}_{1}-\mathrm{C}_{2} & 1.55 & 0.03 \\ \mathrm{C}_{2}-\mathrm{C}_{3} & 1.45 & 0.04 \\ \mathrm{C}_{3}-\mathrm{C}_{4} & 1.48 & 0.03 \\ \mathrm{C}_{6}-\mathrm{C}_{7} & 1.42 & 0.03 \\ \mathrm{C}_{8}-\mathrm{C}_{11} & 1.41 & 0.03 \\ \mathrm{C}_{7}-\mathrm{C}_{8} & 1.37 & 0.03 \\ \mathrm{C}_{8}-\mathrm{C}_{9} & 1.37 & 0.03 \\ \mathrm{C}_{9}-\mathrm{C}_{10} & 1.35 & 0.03 \\ \mathrm{C}_{10}-\mathrm{C}_{11} & 1.33 & 0.03\end{array}$

Acta Chem. Scand. 21 (1967) No. 2 
Table 5. Bond angles in the methyl phenyl phospholanium ion with their standard deviations.

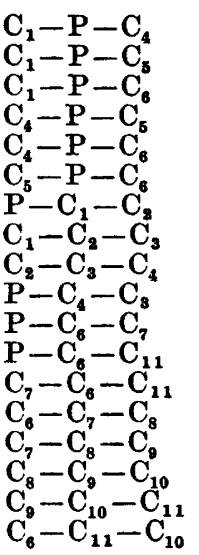

$\begin{array}{rr}\text { Angle }\left({ }^{\circ}\right) & \text { Standard dev } \\ 94.8 & 1.1 \\ 111.1 & 1.3 \\ 111.7 & 1.1 \\ 112.3 & 1.1 \\ 113.6 & -1 \\ 112.2 & 1.0 \\ 107.9 & 1.0 \\ 106.6 & 1.7 \\ 110.3 & 2.1 \\ 106.3 & 2.2 \\ 121.0 & 1.6 \\ 122.0 & 1.6 \\ 117.0 & 1.5 \\ 118.4 & 1.9 \\ 122.5 & 2.2 \\ 118.2 & 2.3 \\ 122.8 & 2.4 \\ 121.0 & 2.4 \\ & 2.0\end{array}$

ions, and two electron density maps were calculated. These two maps made it possible to place the phosphorus atom and all eleven carbon atoms in the asymmetric unit. The final electron density projection along $c$ is shown in Fig. 1.

An attempt was made to refine each projection separately by least squares computation, with the hope of obtaining good approximate coordinates in this way before the more tedious computation on all available data was started. All resulting $x$ and $y$ coordinates seemed satisfactory, but the $z$ coordinates for some carbon atoms partly overlapping in the a projection were unacceptable. Therefore initial $z$ coordinates for these atoms were assigned by use

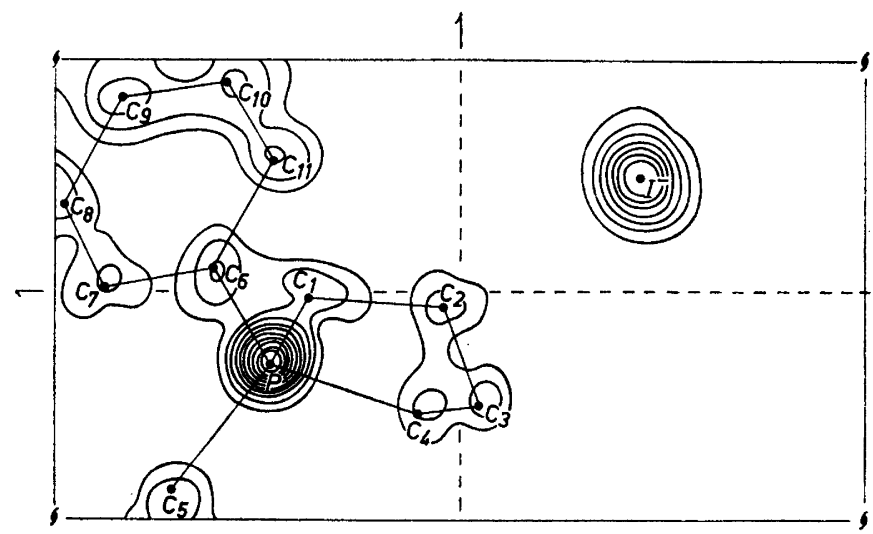

Fig. 1. Final electron density projection along $c$. Contours at $4,6,8, \ldots$ e. $\AA^{-2}$ for phosphorus and carbon atoms, and at $4,14,24, \ldots$ e. $\AA .^{2}$ for the iodide ion. 
of a model of the ion, and the least squares computation on the three-dimensional data was started. Initially, 1211 structure amplitudes were included; later, reflections too weak to be measured with reasonable certainty were excluded. No $F_{\text {o }}$ values for these reflections are given in Table 3.

At a late stage, the sixteen hydrogen atoms were included in the computation, with coordinates assigned by use of a model, assuming normal bond angles and a carbon-hydrogen bond distance of $1.0 \AA$ in the aromatic part and $1.1 \AA$ in the aliphatic part of the ion. Anisotropic temperature factors were then introduced for all atoms except the hydrogen atoms, whose parameters were all kept constant throughout the computation.

When the calculated shifts in atomic parameters became insignificant, the agreement residual $R_{1}$ had reached 0.07 for the 1007 structure amplitudes listed in Table 3. The final positional and thermal parameters are listed in Tables 1 and 2. Bond lengths and bond angles with their standard deviations are given in Tables 4 and 5 . The torsion angles around carbon-carbon and carbon-phosphorus bonds are given in Table 6; no standard deviations have been calculated for these. Bond lengths, bond angles, intramolecular non bond distances and some of the torsion angles are also shown in Fig. 2.

\section{RESULTS AND DISCUSSION}

The four phosphorus carbon bond distances are found to be $1.75,1.76$, 1.78 , and $1.80 \AA$. As the standard deviation is $0.02 \AA$ the differences in bond lengths are not significant. However, the mean value is significantly smaller than the bond length found in trimethylphosphine, 1.84 $\AA$. $^{4}$ This bond distance
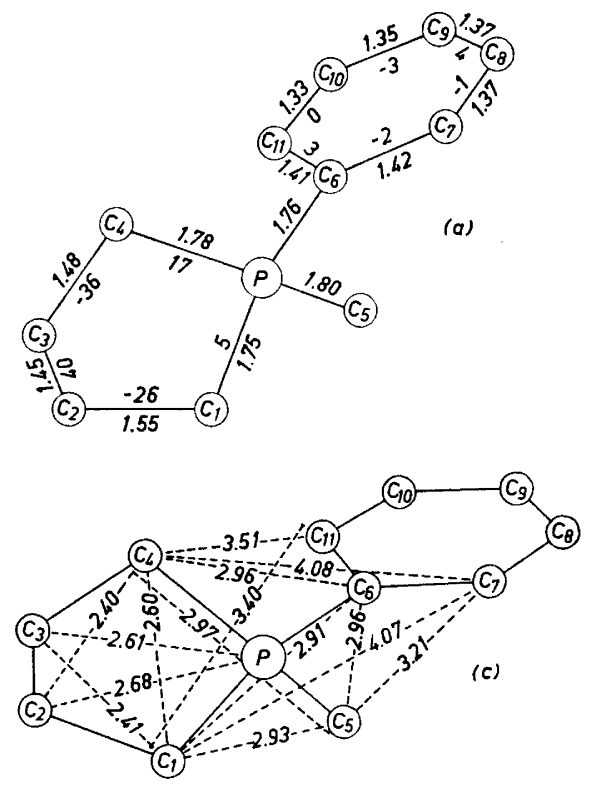

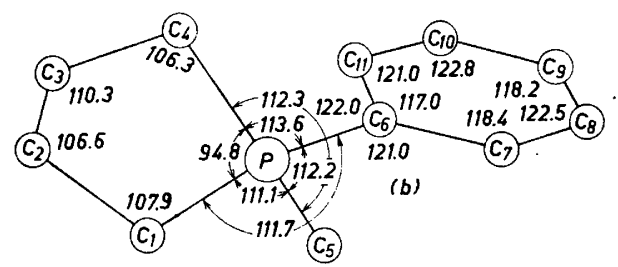

Fig. 2. (a) Bond lengths $(\AA)$ and the torsion angles $\left({ }^{\circ}\right)$ in the two rings, (b) bond angles $\left({ }^{\circ}\right)$, and $(\mathrm{c})$ intramolecular non bond distances $(\AA)$. 
is $0.03 \AA$ smaller than the sum of the covalent radii, and this is the "shortening" expected from the supposed difference in electronegativity between the carbon and the phosphorus atom. ${ }^{4,5}$ In a phosphonium ion the covalent bonds should be more polar in character than the bonds in a phosphine, and accordingly shorter. We therefore regard our mean value, $1.77 \AA$, as reasonable. The mean phosphorus-carbon bond distance found in $\mathrm{AgP}\left(\mathrm{C}_{3} \mathrm{H}_{7}\right)_{3} \mathrm{SCN}, 1.76 \AA{ }^{6}$ seems to support this view.

The standard deviations for carbon-carbon bond lengths are around $\mathbf{0 . 0 3}$ $\AA$, and thus none of the deviations from normal distances are significant. However, the distance $1.45 \AA$ in the phospholanium ring, and $1.33 \AA$ in the benzene ring, seem abnormally short. Similar short bonds have, however, been reported earlier, by Hordvik and Kjøge, ${ }^{7}$ Mani, Ahmed and Barnes, ${ }^{8}$ and Dunitz and Rollett. ${ }^{9}$ Mani et al. ${ }^{8}$ report a mean bond length of $1.377 \AA$ in a phenyl group, we find $1.375 \AA$. We suspect that at least in our case the "short bonds" may rather result from the block diagonal least squares method used. Such an explanation is also suggested by Dunitz and Rollett in the case of dibenzylphosphate. ${ }^{9}$

The phenyl group is planar within the experimental error. The carbon atom of the methyl group is very close to the plane of the phenyl group, as shown by the intramolecular distances, Table 7, and by the torsion angles, Table 6.

None of the angles in the phenyl group deviate significantly from $120^{\circ}$. The angles around the phosphorus atom are all about $112^{\circ}$, except the angle in the phospholane ring, which is $95^{\circ}$. The unsymmetrical distribution of bond

Table 6. Torsion angles in the methyl phenyl phospholanium ion. $\mathbf{P}-\mathbf{C}_{1}-\mathbf{C}_{2}-\mathbf{C}_{3}-25.56$ means that the torsion angle around $C_{1}-C_{2}$, between $P-C_{1}$ and $C_{2}-C_{3}$, (i.e. the angle between the normals to the planes through $P, C_{1}$, and $C_{2}$, and through $C_{1}, C_{2}$, and $C_{3}$ ) is $25.56^{\circ}$, and that the torsion is to the left (counterclockwise) when seen along $\mathrm{C}_{1}-\mathrm{C}_{2}$ in that direction.

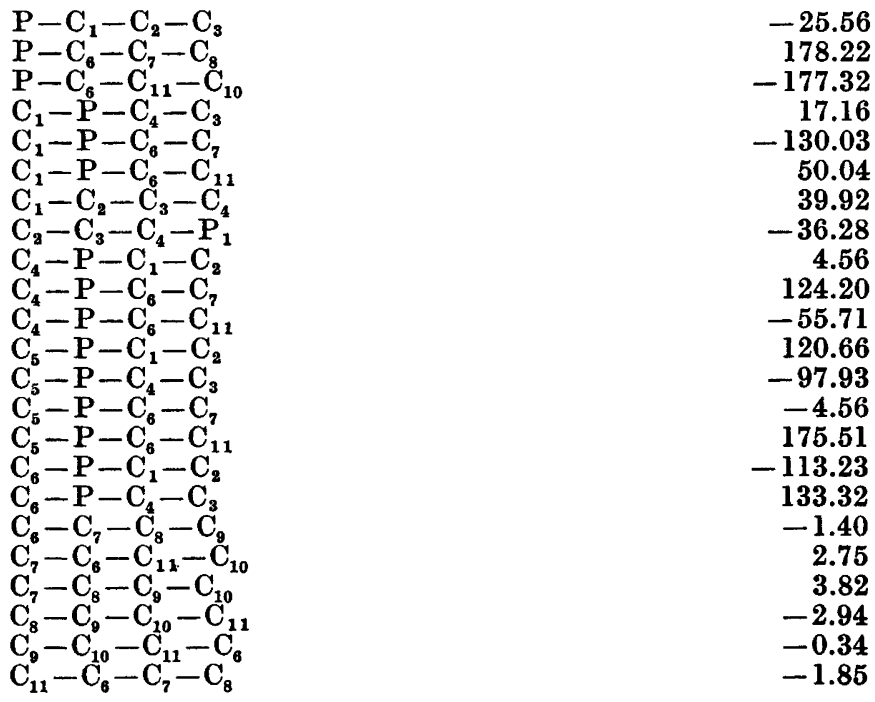

Acta Chem. Scand. 21 (1967) No. 2 
Table 7. Intramolecular non bond distances in the methyl phenyl phospholanium ion.

$\begin{array}{lc}\text { Atoms } & \text { Distance }(\AA) \\ \mathrm{P}-\mathrm{C}_{2} & 2.68 \\ \mathrm{P}-\mathrm{C}_{3} & 2.61 \\ \mathrm{C}_{1}-\mathrm{C}_{3} & 2.41 \\ \mathrm{C}_{1}-\mathrm{C}_{4} & 2.60 \\ \mathrm{C}_{2}-\mathrm{C}_{4} & 2.40 \\ \mathrm{C}_{1}-\mathrm{C}_{5} & 2.93 \\ \mathrm{C}_{4}-\mathrm{C}_{6} & 2.97 \\ \mathrm{C}_{1}-\mathrm{C}_{6} & 2.91\end{array}$

$\begin{array}{lc}\text { Atoms } & \text { Distance }(\AA) \\ C_{4}-C_{8} & 2.96 \\ C_{5}-C_{6} & 2.96 \\ C_{1}-C_{7} & 4.07 \\ C_{4}-C_{7} & 4.08 \\ C_{1}-C_{11} & 3.40 \\ C_{4}-C_{11} & 3.51 \\ C_{5}-C_{7} & 3.21\end{array}$

directions around the phosphorus atom may, at least partly, be responsible for the higher reactivity of the methyl phenyl phospholanium ion as compared with the ion $\mathrm{CH}_{3}\left(\mathrm{C}_{6} \mathrm{H}_{5}\right) \mathrm{P}^{+}\left(\mathrm{CH}_{2}\right)_{5}$, which contains a six-membered ring. ${ }^{1}$

The sum of the angles in the phospholane ring is found to be $526^{\circ}$, vs. $540^{\circ}$ in a planar pentagon. The mean of angles at the four carbon atoms is about $108^{\circ}$, and none of the individual values, $106^{\circ}, 107^{\circ}, 108^{\circ}$, and $110^{\circ}$, deviates significantly from the mean. The carbon atom $\mathrm{C}_{2}$ (Fig. 2) is very close to the plane through the phosphorus atom and its two adjacent carbon atoms $\mathbf{C}_{1}$ and $\mathrm{C}_{4}$, while $\mathrm{C}_{3}$ is out of this plane.

In the gauche configuration of butane the torsion angle around the central bond, i.e. the angle between the normals to the planes through atoms Nos. 1 , 2 , and 3, and through atoms Nos. 2, 3, and 4, is $60^{\circ}$. This corresponds to a minimum in the hydrogen-hydrogen repulsion. The configuration of the four carbon atoms in the phospholane ring is similar, but the torsion angles are smaller, as shown in Table 6 and Fig. 2. Larger torsion angles around the bonds of the ring imply smaller average bond angles in the ring. The structure thus seems a compromise between "non bond net repulsion" and "bond angle strain".

Table 8. Interionic distances. Signs indicate the directions of the $z$ components when two distances overlap in the $c$ projection (Fig. 3).

\begin{tabular}{|c|c|c|c|}
\hline Atoms & Distance $(\AA)$ & Atoms & Distance $(\AA)$ \\
\hline $\begin{array}{l}I-P \\
I-P \\
I-P \\
I-C_{2} \\
I-C_{3} \\
I-C_{4} \\
I-C_{6} \\
I-C_{10} \\
I-C_{11} \\
I-C_{1} \\
I-C_{2} \\
I-C_{4} \\
I-C_{4} \\
I-C_{5} \\
I-C_{5} \\
I-C_{9} \\
I-C_{10}\end{array}$ & $\begin{array}{r}4.98 \\
+4.71 \\
-4.28 \\
4.23 \\
4.03 \\
3.90 \\
4.97 \\
4.88 \\
4.19 \\
4.36 \\
4.60 \\
+4.93 \\
-3.95 \\
+3.91 \\
-3.87 \\
4.68 \\
4.22\end{array}$ & $\begin{array}{l}\mathrm{C}_{1}-\mathrm{C}_{3} \\
\mathrm{C}_{1}-\mathrm{C}_{4} \\
\mathrm{C}_{3}-\mathrm{C}_{10} \\
\mathrm{C}_{4}-\mathrm{C}_{2} \\
\mathrm{C}_{4}-\mathrm{C}_{10} \\
\mathrm{C}_{4}-\mathrm{C}_{11} \\
\mathrm{C}_{5}-\mathrm{C}_{5} \\
\mathrm{C}_{5}-\mathrm{C}_{8} \\
\mathrm{C}_{6}-\mathrm{C}_{5} \\
\mathrm{C}_{6}-\mathrm{C}_{9} \\
\mathrm{C}_{7}-\mathrm{C}_{5} \\
\mathrm{C}_{7}-\mathrm{C}_{9} \\
\mathrm{C}_{8}-\mathrm{C}_{10} \\
\mathrm{C}_{8}-\mathrm{C}_{10} \\
\mathrm{C}_{9}-\mathrm{C}_{8} \\
\mathrm{C}_{9}-\mathrm{C}_{8} \\
\mathrm{C}_{9}-\mathrm{C}_{9}\end{array}$ & $\begin{array}{r}4.28 \\
4.58 \\
4.30 \\
4.10 \\
3.99 \\
4.48 \\
4.27 \\
4.21 \\
4.86 \\
4.04 \\
3.73 \\
3.92 \\
+4.60 \\
3.96 \\
+4.12 \\
-3.79 \\
3.70\end{array}$ \\
\hline
\end{tabular}

Acta Chem. Scand. 21 (1967) No. 2 
It should perhaps be pointed out that the seemingly small bond angle of $95^{\circ}$ at the phosphorus atom may not be a result of the torsions around the bonds in the phospholane ring, but rather due to the fact that carbon-phosphorus bonds are longer than carbon-carbon bonds.

The five-membered ring in the methyl phenyl phospholanium ion appears to be asymmetrical. As shown in Fig. 2 the torsion angles around the five bonds of the ring, starting at the phosphorus atom and going round the ring are, $5^{\circ}, 25^{\circ}, 40^{\circ}, 36^{\circ}$, and $17^{\circ}$, the torsion alternating right and left. A reasonable explanation might be that the phenyl and methyl groups do not take up equally much space, and thus methylene groups adjacent to phosphorus will twist more easily one way than the other. It is shown in Table 8 and Fig. 3 that the packing of iodide ions around the cation is asymmetrical. As the iodide ions may influence the hydrogen atom repulsion, this may also constitute part of the explanation of the asymmetry of the phospholane ring in the present case.

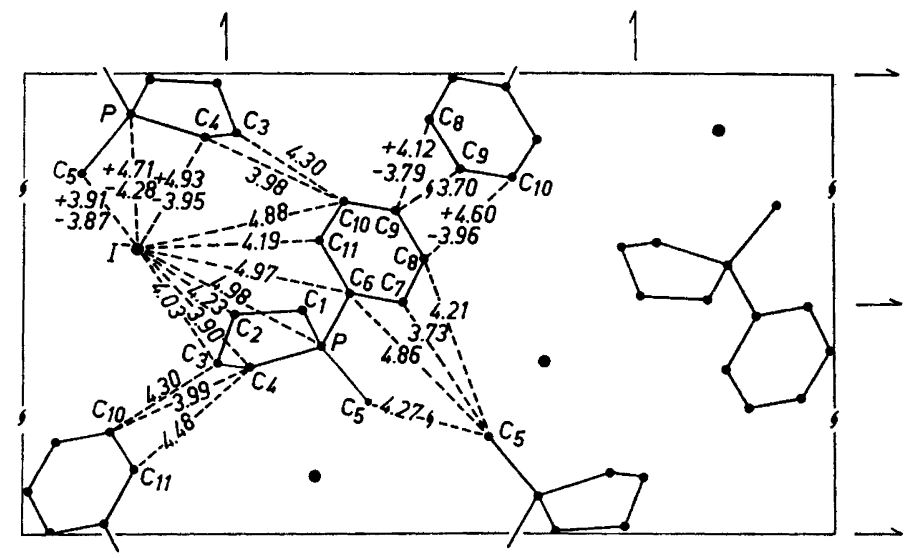

Fig. 3. The packing of the ions as seen along $c$, with interionic distances $(\AA)$. The signs + and - indicate the directions of the $z$ components of the respective distances.

For comparison, we have calculated torsion angles in two other fivemembered rings from data given in recent papers. In 3,3,4,4-tetrahydrofurantetrol ${ }^{10}$ there should be no reason for asymmetry, and the molecule has, apparently, a dyad rotation axis. The torsion angles were found to be $13^{\circ}$, $3^{\circ}, 40^{\circ}, 33^{\circ}$, and $14^{\circ}$, starting at the oxygen atom. In methyl ethylene phosphate ${ }^{11}$ the torsion angles were found to be $2^{\circ}, 13^{\circ}, 20^{\circ}, 20^{\circ}$, and $11^{\circ}$, taken in the same order as in the phospholane ring. Thus it seems that these two rings are asymmetrical in much the same way, but presumably for different reasons. In methyl ethylene phosphate there are no hydrogen atoms attached to the atoms adjacent to phosphorus, but the double bond character of the phosphorus-oxygen bonds and the apparent interaction between the methyl group and one of the oxygen atoms in the ring may explain the asymmetry. 
More examples will not be discussed here, but we should like to mention that it has been reported by Brown and Lingafelter that five membered rings in copper(II) ethylenediamine complexes are asymmetrical..$^{12}$

The packing of the ions in the crystals of methyl phenyl phospholanium iodide is shown in Fig. 3, and the inter-ionic distances are listed in Table 8. The iodide ions have their shortest contacts to methyl groups, 3.87 and 3.91 $\AA$, and to atoms $\mathrm{C}_{4}$ that are bonded to the phosphorus atoms and belong to the phospholane ring, 3.90 and $3.95 \AA$.

It can hardly be concluded from our data how much the structure of the cation is affected by its contacts with neighbouring ions. We believe the possible influence to be small, except when hydrogen atoms are concerned.

The asymmetry of the five-membered ring implies the existence of two mirror image forms of the methyl phenyl phospholanium ion. In a single crystal of the present salt, based on an enantiomorphous space group, only one of the enantiomorphs occurs.

Most of the computation was carried out on the IBM $1620^{\text {II }}$ electronic computer with programs by Shiono, ${ }^{13}$ Ahmed ${ }^{14}$ and Mair. ${ }^{14}$

We are most grateful to the staff of the computing department. We are also indebted to cand. real. $\mathbf{K}$. Bergesen for supplying us with crystals.

\section{REFERENCES}

1. Aksnes, G. and Bergesen, K. Acta Chem. Scand. 19 (1965) 931.

2. International Tables for X-Ray Crystallography, Kynoch Press, Birmingham 1962, Vol. III, p. 140.

3. Pinnock, P. R., Taylor, C. A. and Lipson, H. Acta Cryst. 9 (1956) 173.

4. Lide, D. R. and Mann, D. E. J. Chem. Phys. 28 (1958) 572.

5. Coulson, C. A. Valence, Oxford University Press 1963, p. 188.

6. Panattoni, C. and Frasson, E. Acta Cryst. 16 (1963) 1258.

7. Hordvik, A. and Kjøge, H. M. Acta Chem. Scand. 19 (1965) 935.

8. Mani, N. V., Ahmed, F. R. and Barnes, W. H. Acta Cryst. 19 (1965) 693.

9. Dunitz, J. and Rollett, A. Acta Cryst. 9 (1956) 327.

10. Michell, A. D. and Jacobson, R. A. Acta Cryst. 19 (1965) 1556.

11. Steitz, T. A. and Lipscomb, W. N. J. Am. Chem. Soc. 87 (1965) 2488.

12. Brown, B. W. and Lingafelter, E. C. Acta Cryst. 17 (1964) 254.

13. Shiono, R. Intensity Correction Program for Normal Beam or Equi-Inclination Weis. senberg Diagrams with or without Extended Spots Correction for IBM 1620, Technical Report No. 43, The Crystallography Laboratory, The University of Pittsburg, USA.

14. Ahmed, F. R. 3-D Fourier Program for the IBM Computer; Mair, G. A. Structure Factor and Least Squares Programs for the IBM 1620, Pure Chemistry Division, National Research Council, Ottawa, Canada 1963.

Received September 7, 1966. 